Volume 8

Issue 2 July

Article 2

July 1981

\title{
Women and Disability: The Double Handicap
}

Nancy Brooks

Mary Jo Deegan

Follow this and additional works at: https://scholarworks.wmich.edu/jssw

Part of the Gender and Sexuality Commons, and the Social Work Commons

\section{Recommended Citation}

Brooks, Nancy and Deegan, Mary Jo (1981) "Women and Disability: The Double Handicap," The Journal of Sociology \& Social Welfare: Vol. 8 : Iss. 2 , Article 2.

Available at: https://scholarworks.wmich.edu/jssw/vol8/iss2/2 
WOMEN AND DISABILITY: THE DOUELE HANDICAP

INTRODUCTION

During the 1970's a social movement arose to address the concerns of people with disabilities. Action groups pressed for reforms in architectural barriers, educational and employment opportunities, deinstitutionalization, and legal protection of civil rights. Altnough accurate demographic information is lacking, estimates indicate that approximately one in ten Americans has a disability or chronic disease and would be affected by the changes brought about by the disability movement. These people experience serious limitations in major activities such as housework, employment, or education. Yet external restrictions imposed by negative attitudes impose greater handicaps by preventing full social participation of this stigmatized group. The primary purpose of the disability movement has been to combat these environmental and social handicaps through public education and legal advances.

Despite the attention given to disability in general and certain impairments in particular, one category within the disabled population has received little recognition or study: women. Like many reform movements, the disability movement has of ten directed its energies toward primarily male experiences; spinal cord injury and employment issues have received more publicity than arthritis or chili-bearing problems. It is the purpose of this special issue to identify the issues and experiences which are particular to disabled women.

\section{THE ISSUE}

The papers assembled here are ample documentation of the special barriers to and strengths of physically disabled women. The papers have been organized so that general issues are introduced, followed by Juliett Mitchell's four categories of structural factors limiting women's lives and opportunities (1971). According to Mitchell, all four areas must change in order to achieve the liberation potential of women. Although the selections were not solicited, nor subritted, using Mitchell's agenda, these areas "naturally" arose as the concerns of our authors.

Although the papers inciuded here are all outstanding and in the forefront of change, there is little overt, political action advocated. Simultaneously, there is a minimum amount of anger or enrotion expressed about the lived reality of this population. This is partially due to the expectations of "academic" writing and reviewers. Yet this is an absence 
that needs to be noted and addressed.

The statuses of physically disabled vomen are often financially marginal. Their access to information about their sexuality and reproductive abilities and rights is of ten severely curtailed. Moreover, they are frequently victimized as children and taught "implicitly" and with "good intentions" that their social acceptability and participation should and ought to be limited. These are grave injustices, and passion and anger are integral steps in motivating people for social action.

We hope that our readers will be aided by our collective documentation to understand the structural inequality that physically disabled women confront. But awareness and toleration of this situation are two separate issues.

Therefore, as the editors we would like to explicitly state that the minority group status of physically disabled women calls for dramatic social change. Provision of this information is but one step in implementing social policies and interpersonal responses that would alter the present inequities.

\section{A NOTE OF APPRECIATION}

In preparing this special issue we owe thanks to a number of people. Norman Gofoff, then editor of The Journal of Sociology and Social Welfare, was the person who introduced us to each other and encouraged our coeditorship on the topic of the physically disabled. After a rather slow start, we found that we did, indeed, have mutual interests. From our telephone conversations we finally decided on this topic, especially during 1981, the United Nations Year of the Physically Disatled. Bob Leighninger and his staff have also been supportive of our endeavor. Both of our Deans have aided in this venture by supplying the funds for advertisements, mailing, xeroxing, and telephone calls. Therefore, we owe a special note of thanks to Max Larsen, Dean of Arts and Sciences at the University of Nebraska-Lincoln and to Lloyd Benningfield, Dean of the Graduate School at Wichita State University. We would also like to thank Margaret Zahn for supplying us with the names of sociologists who were members of the sub-section on disability in the American Sociological Associations' Medical Sociology section.

Our reviewers have also carefully and quickly responded to our requests for help. Their names are published on page 4 here.

We also want to acknowledge the many physically disabled women we have known and who have supported this project. We hope that they are pleased with it, as we are. 
Finally, we would like to say that this special issue afforded both of us the opportunity to edit an issue that we consider of extreme importance both professionally and personally. We have had a good relationship with each other, and it is this interdependence and co-operation which has helped produce this final product.

Nancy Brooks, Wichita State University

Mary Jo Deegan, University of NebraskaLincoln 


\section{REVIEWERS}

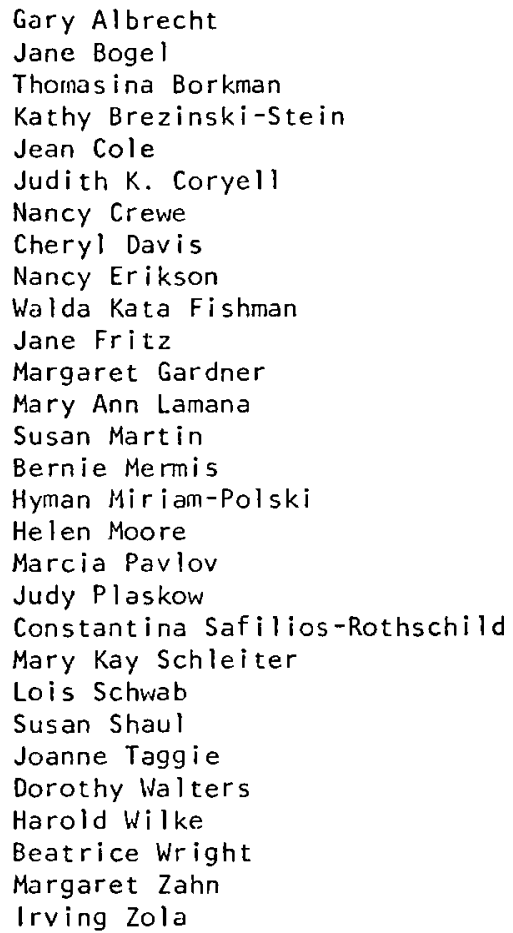

